\title{
Article \\ Alleviation of Copper-Induced Stress in Pea (Pisum sativum L.) through Foliar Application of Gibberellic Acid
}

\author{
Talha Javed ${ }^{1,2,+}+\mathbb{D}_{\text {, Muhammad Moaaz Ali }}^{3,+}+\mathbb{D}$, Rubab Shabbir ${ }^{1}$, Raheel Anwar ${ }^{4}\left(\mathbb{D}\right.$, Irfan Afzal ${ }^{2}$ (D) and \\ Rosario Paolo Mauro ${ }^{5, *}$ (D)
}

check for updates

Citation: Javed, T.; Ali, M.M.; Shabbir, R.; Anwar, R.; Afzal, I.; Mauro, R.P. Alleviation of Copper-Induced Stress in Pea (Pisum sativum L.) through Foliar Application of Gibberellic Acid. Biology 2021, 10, 120. https://doi.org/10.3390/ biology10020120

Academic Editor: Stefano Loppi Received: 6 December 2020

Accepted: 31 January 2021

Published: 5 February 2021

Publisher's Note: MDPI stays neutral with regard to jurisdictional claims in published maps and institutional affiliations.

Copyright: (c) 2021 by the authors. Licensee MDPI, Basel, Switzerland. This article is an open access article distributed under the terms and conditions of the Creative Commons Attribution (CC BY) license (https:// creativecommons.org/licenses/by/ $4.0 /)$.
1 College of Agriculture, Fujian Agriculture and Forestry University, Fuzhou 350002, China; talhajaved54321@gmail.com (T.J.); rubabshabbir28@gmail.com (R.S.)

2 Seed Physiology Lab, Department of Agronomy, University of Agriculture, Faisalabad 38040, Pakistan; irfanuaf@gmail.com

3 College of Horticulture, Fujian Agriculture and Forestry University, Fuzhou 350002, China; muhammadmoaazali@yahoo.com

4 Institute of Horticulture Sciences, University of Agriculture, Faisalabad 38040, Pakistan; raheelanwar@uaf.edu.pk

5 Dipartimento di Agricoltura, Alimentazione e Ambiente (Di3A), Università degli Studi di Catania, Via Valdisavoia, 5-95123 Catania, Italy

* Correspondence: rosario.mauro@unict.it; Tel.: +39-95-478-3314

+ These authors contributed equally to this work.

Simple Summary: Phytohormones are key regulators of several stages of plant growth and development as well as provide the regulatory response against various heavy metals stresses by mediating physio-morphological responses and enzymatic activities. The current study evaluated the effects of gibberellic acid $\left(\mathrm{GA}_{3}\right)$ foliar applications on the performance of pea grown either in Cu-contaminated $(\mathrm{Cu}+)$ and non-contaminated $(\mathrm{Cu}-)$ soil. $\mathrm{GA}_{3}$ was applied exogenously $\left(0,10,50\right.$, and $\left.100 \mathrm{mg} \cdot \mathrm{L}^{-1}\right)$ on 15-days-old plants, and the results show that the increasing concentration of $\mathrm{GA}_{3}$ buffered the phytotoxic effects of $\mathrm{Cu}$, coupled with an increase in plant growth and physiological variables. The results also showed that foliar-applied $\mathrm{GA}_{3}$ up to $100 \mathrm{mg} \cdot \mathrm{L}^{-1}$ alleviated the oxidative stress, as inferred from the lower concentrations of malondialdehyde (MDA) and $\mathrm{H}_{2} \mathrm{O}_{2}$, which mirrored the increased activity of antioxidant enzymes, i.e., superoxide dismutase, peroxidase, and catalase. In addition, enhanced growth, physiology, and enzymatic activities were also observed in pea plants sprayed with $\mathrm{GA}_{3}$ up to $100 \mathrm{mg} \cdot \mathrm{L}^{-1}$ in $\mathrm{Cu}$ - soil. Overall, the foliar application of $\mathrm{GA}_{3}$ boosted phytoextraction of $\mathrm{Cu}$ from the soil and alleviated the oxidative stress in pea plants grown in $\mathrm{Cu}$-polluted soil.

Abstract: Copper $(\mathrm{Cu})$ is an essential metal for plants. However, its excess in soil can adversely affect plant metabolism. The current study evaluated the effects of gibberellic acid $\left(\mathrm{GA}_{3}\right)$ foliar applications on the performance of pea plants grown either in $\mathrm{Cu}$-contaminated $(\mathrm{Cu}+)$ and non-contaminated $(\mathrm{Cu}-)$ soil. $\mathrm{GA}_{3}$ was sprayed $\left(0,10,50\right.$, and $\left.100 \mathrm{mg} \cdot \mathrm{L}^{-1}\right)$ on 15 -days-old plants. The results showed that the increasing concentration of $\mathrm{GA}_{3}$ buffered the phytotoxic effects of $\mathrm{Cu}$ and enhanced plant growth, photosynthesis, and leaf chlorophyll content. Foliar-sprayed $\mathrm{GA}_{3}$ up to $100 \mathrm{mg} \cdot \mathrm{L}^{-1}$ alleviated the oxidative stress, as inferred from the lower concentrations of MDA and $\mathrm{H}_{2} \mathrm{O}_{2}\left(33.3 \mu \mathrm{mol} \cdot \mathrm{g}^{-1}\right.$ and $182 \mu \mathrm{mol} \cdot \mathrm{g}^{-1}$, respectively), and boosted the activity of superoxide dismutase $\left(64.4 \mathrm{U} \cdot \mathrm{g}^{-1} \cdot \mathrm{FW}\right)$, peroxidase $\left(122.7 \mathrm{U} \cdot \mathrm{g}^{-1} \cdot \mathrm{FW}\right)$, and catalase $\left(226.3 \mathrm{U} \cdot \mathrm{g}^{-1} \cdot \mathrm{FW}\right)$. Interestingly, $\mathrm{GA}_{3}$ promoted $\mathrm{Cu}$ accumulation in different plant parts when compared to untreated plants, likely due to increased photosynthetic and transpiration rates. Overall, foliar application of $\mathrm{GA}_{3}$ promoted phytoextraction of $\mathrm{Cu}$ and alleviated the oxidative stress in pea plants grown in $\mathrm{Cu}+$ soil.

Keywords: Pisum sativum L.; copper and oxidative stresses; gibberellic acid; foliar application 


\section{Introduction}

Pea (Pisum sativum L.) is an important leguminous crop, whose high protein content (up to $22-23 \%$ ) is almost three times that of cereals [1]. The crop is mainly cultivated in tropical and sub-tropical regions of the world, and has the ability of nitrogen $(\mathrm{N})$ fixation in soil through $\mathrm{N}$ fixing bacteria residing in roots. It has a deep root system, and hence is highly drought tolerant [2]. It has good nutritive value, as it contains considerable amounts of lysine, thiamine, riboflavin, iron, and niacin, and its product is represented by green pods or mature seeds as meal worldwide [2]. In pea, physio-morphological and biochemical events are the most crucial on which the whole productivity relies, and both are influenced by metals toxicity [3]. Heavy metals contamination is becoming increasingly common in many agricultural farmlands worldwide, due to long-term mining activities which endanger crops yield and food security [4,5]. This feature is of major concern in agricultural systems, due to the adverse effects on crop growth and physiology (phytotoxicity), food safety and marketability, soil micro biota, and most importantly on human health [6]. In addition, the dynamic equilibrium between production and elimination of reactive oxygen species (ROS) under normal growth conditions can be altered due to toxic levels of heavy metal, which results in disruption of structure and functioning of cell membranes as a result of lipid peroxidation, malondialdehyde (MDA), and hydrogen peroxide $\left(\mathrm{H}_{2} \mathrm{O}_{2}\right)$ accumulation [7]. Nevertheless, remediation of metal-contaminated soils by conventional (physical and chemical) methods is not ideal, as it requires huge resources, is time consuming, and sometimes even environmentally hazardous [8]. However, more recent emerging technologies, such as exogenous application of phyto-hormones, due to their ease, efficiency, and environmentally friendliness for phytoremediation should be considered for remediation [4].

Gibberellic acid $\left(\mathrm{GA}_{3}\right)$ is a plant hormone involved in several stages such as cell division, plant height, tissue differentiation, dry matter accumulation, net assimilation rate, leaf expansion, elongation, flowering, photosynthesis, and transpiration rate [9-11]. In addition, $\mathrm{GA}_{3}$ is a kind of diterpenoid compound, and is known to play key roles to enhance phytoremediation efficiency of many crops by mediating physiology, morphology, and enzymatic activities $[12,13]$. Previous literature reported that exogenous supplementation of $\mathrm{GA}_{3}$ as foliar spray significantly enhanced growth and phytoextraction efficiency of different crop plants such as Zea mays L., Tagetes patula L., Solanum nigrum L., and Corchorus capsularis L. grown on $\mathrm{Cu}$, cadmium $(\mathrm{Cd})$, lead $(\mathrm{Pb})$, and benzo[a]pyrene-contaminated soil [4,13-15].

Exogenous applications of $\mathrm{GA}_{3}$ have a remarkable role in S. nigrum for substantial increases in growth and development [13]. In addition, a considerable increase in growth and biomass accumulation of Carapichea ipecauanha was observed in plants that received foliar applied $\mathrm{GA}_{3}$ as compared to untreated plants [16]. Previous literature also reported the protective role of $\mathrm{GA}_{3}$ with improved photosynthetic performances in chromium $(\mathrm{Cr})$ contaminated soil [10]. The possible reason behind this mechanism might be the enhanced antioxidant activities that reduced the oxidative damage of Corchorus capsularis L. plants growing in $\mathrm{Cu}$-contaminated soil [4]. There is a lot of literature on exogenous supplementation of $\mathrm{GA}_{3}$ to enhance plant growth and development in metal-contaminated soil, however, available on other plant species, such as and Solanum nigrum L., and Tagetes patula L. [12,15]. The uniqueness of Pisum sativum L. plants due to high nutritive value and negative impacts of $\mathrm{Cu}$ on human health demands phytoremediation; however, sufficient information is not available regarding $\mathrm{Cu}$ tolerance, antioxidative defense mechanism, and $\mathrm{Cu}$ accumulation in different parts of this species, when grown under different concentrations of foliar applied $\mathrm{GA}_{3}$. Therefore, it is vital to explore the protective and growth promoting role of $\mathrm{GA}_{3}$ in $\mathrm{Cu}$-contaminated soils. It may be hypothesized that $\mathrm{GA}_{3}$ alleviates $\mathrm{Cu}$ and oxidative stresses by modulating some physio-morphological and biochemical processes in pea. To test this hypothesis, pea plants were germinated on $\mathrm{Cu}$-contaminated soil and then foliar sprayed with 10,50 , and $100 \mathrm{mg} \cdot \mathrm{L}^{-1} \mathrm{GA}_{3}$ at 15 days after germination. In addition to evaluating key stress benchmarks on plant growth (plant height, plant weight, leaf chlorophyll, photosynthesis, and transpiration rates), accumulation of electrolytes, $\mathrm{H}_{2} \mathrm{O}_{2}$ 
and MDA, and activities of key of radical oxygen-scavenging enzymes catalase, peroxidase, and superoxide dismutase were also quantified.

\section{Materials and Methods}

\subsection{Experimental Site and Growth Conditions}

The soil for the pot experiment was collected from the Research Area, Department of Agronomy, University of Agriculture, Faisalabad City, Punjab Province, Pakistan $\left(30.37^{\circ} \mathrm{N}\right.$, $69.34^{\circ} \mathrm{E}$ ) at depth of $0-20 \mathrm{~cm}$. After grinding, the soil was mixed thoroughly, air dried under shade, and sieved through a $5 \mathrm{~mm}$ sieve before filling in pots (10 kg soil per pot). The textural class of soil for experimentation was loam and, before the start of the experiment, had the following characteristics: Electrical conductivity (EC) $0.432 \mathrm{dSm}^{-1}, \mathrm{pH}$ 7.5 , available $\mathrm{K} 344 \mathrm{mg} \cdot \mathrm{kg}^{-1}$, available P $12.21 \mathrm{mg} \cdot \mathrm{kg}^{-1}$, and $\mathrm{Cu} 109 \mathrm{mg} \cdot \mathrm{kg}^{-1}$. Total $\mathrm{Cu}$ $\left(2000 \mathrm{mg} \cdot \mathrm{kg}^{-1}\right)$, as $\mathrm{CuSO}_{4} \cdot 5 \mathrm{H}_{2} \mathrm{O}$, was mixed thoroughly in soil prior to filling in pots, to simulate $\mathrm{Cu}$ contamination $(\mathrm{Cu}+$ soil) [4]. The same number of experimental units without $\mathrm{Cu}$ addition in the soil were included as control $(\mathrm{Cu}-$ soil). A pea variety with indeterminate growth habit, "Sarsabz" (Pisum sativum L.) with 98\% germination capacity was procured from Ayub Agricultural Research Institute, Faisalabad, Pakistan and used throughout the course of the experiment. The experiment was conducted in the glasshouse at the Research Area, Department of Agronomy, University of Agriculture, Faisalabad, from November 2018 to January 2019. Plants in the glasshouse received natural light, with day/night average temperature of $26 / 15^{\circ} \mathrm{C}$ and day/night average humidity of $65 / 80 \%$. The bi-factorial experiment was laid out under completely randomized design (CRD), with four replications (each replication contained five pots for each treatment). Ten seeds were directly sown in each pot. Each replication contained 50 plants of each experimental unit. Irrigation, weeding, and necessary agronomic practices, based on physical observations, were done when needed.

\subsection{Exogenous Application of $G A_{3}$}

Foliar sprays of $\mathrm{GA}_{3}$ were done 14 days after seeding. From 10:00 until 11:00 am, treatments, i.e., $0,10,50,100 \mathrm{mg} \cdot \mathrm{L}^{-1}$ were applied by exogenously spraying $\mathrm{GA}_{3}$ on whole seedlings until solution falls and treatments were applied only once during the whole experiment [4].

\subsection{Plant Growth Attributes}

Five uniform plants were randomly selected from each replication to determine the number of leaves, plant height, and plant relative fresh and dry weights at 40 days after seeding (DAS). To determine relative fresh and dry weights, plants were washed with distilled water, dried with paper and weighed for their fresh weight followed by oven drying at $70{ }^{\circ} \mathrm{C}$ until constant weight achieved. After oven drying, dry weights were recorded.

\subsection{Physiological Variables}

At 40 DAS from five uniform randomly selected plants from each replication, leaf chlorophyll content was measured with a chlorophyll SPAD meter (CCM-200 plus, OptiSciences, Hudson, NH, USA) according to manufacturer's instructions, and presented as SPAD values. On the same date measurements of net photosynthetic rate $(\mu \mathrm{mol}$ $\left.\mathrm{CO}_{2} \mathrm{~m}^{-2} \cdot \mathrm{s}^{-1}\right)$, stomatal transpiration rate $\left(\mathrm{mmol} \mathrm{H}_{2} \mathrm{O} \mathrm{m}{ }^{-2} \cdot \mathrm{s}^{-1}\right)$, and $\mathrm{CO}_{2}$ concentration $\left(\mu \mathrm{mol} \cdot \mathrm{mol}^{-1}\right)$ were made on fully expanded leaves from the top of the plant canopy by using an open system LCA-4 (ADC BioScientific Ltd., Hoddesdon, UK). These measurements were made from 10:00 to 11.00 a.m., with the following specifications: Ambient pressure (P) $88.76 \mathrm{kPa}$, molar flow of air per unit leaf area (Us) $201.89 \mathrm{~mol} \mathrm{~m}^{-2} \cdot \mathrm{S}^{-1}$, temperature of leaf chamber (Tch) varied from 38.9 to $42.4{ }^{\circ} \mathrm{C}$, leaf chamber molar gas flow rate (U) $236 \mu \mathrm{mol} \cdot \mathrm{S}^{-1}$, leaf surface area $10.11 \mathrm{~cm}^{2}$, and photosynthetically active radiation (PAR) at leaf surface was maximum up to $887 \mu \mathrm{mol} \mathrm{m}{ }^{-2} \cdot \mathrm{s}^{-1}$. 


\subsection{Oxidative Stress Indicators and Antioxidant Response}

To determine malondialdehyde (MDA) content, an indicator of lipid peroxidation, $0.1 \mathrm{~g}$ leaves were ground with $25 \mathrm{~mL}$ of $50 \mathrm{mM}$ phosphate buffer solution containing $1 \%$ polyethylene pyrrole with the help of pestle and mortar. After centrifugation at $12,000 \times g$ for $15 \mathrm{~min}$ at $4{ }^{\circ} \mathrm{C}$, the supernatant was taken, followed by heating at $100^{\circ} \mathrm{C}$ for $20 \mathrm{~min}$. The tubes were quickly cooled in an ice bath after heating. The absorbance was taken at wavelengths of 532, 600, and $450 \mathrm{~nm}$ by using a spectrophotometer (T60 U Spectrophotometer, PG Instruments Ltd., Leicestershire, UK) [17].

To determine $\mathrm{H}_{2} \mathrm{O}_{2}$ concentration, leaf samples $(1 \mathrm{~g})$ were ground in $9 \mathrm{~mL}$ of normal saline solution $(4.5 \mathrm{~g} \mathrm{NaCl}$ added in $500 \mathrm{~mL}$ ddH2O) followed by centrifugation at $10,000 \times g$ for $10 \mathrm{~min}$. Three tube types were prepared, namely empty, standard, and sample tubes. Briefly, reagent 1 and $2(1.0 \mathrm{~mL})$ in all tubes, $\mathrm{H}_{2} \mathrm{O}(0.1 \mathrm{~mL})$ in empty tube, standard solution $(0.1 \mathrm{~mL})$ in standard tube, and sample $(0.1 \mathrm{~mL})$ in sample tube was added. The absorbance was taken at $405 \mathrm{~nm}$ with spectrophotometer according to $\mathrm{H}_{2} \mathrm{O}_{2}$ determination kit (Nanjing Jiancheng Biology Co., Ltd., Nanjing, China).

To determine electrolyte leakage (EL), fully expanded leaves from the top of the plant canopy were taken, followed by cutting into minor slices $(5-6 \mathrm{~mm}$ length), placed in sterilized test tubes having $8 \mathrm{~mL}$ distilled water, incubated, and transferred to water bath for $12 \mathrm{~h}$ prior to measuring the initial electrical conductivity $\left(\mathrm{EC}_{1}\right)$. After measuring the initial $\mathrm{EC}_{1}$, samples were autoclaved at $121^{\circ} \mathrm{C}$ for $20 \mathrm{~min}$ followed by cooling down to $25^{\circ} \mathrm{C}$ to measure the final electrical conductivity $\left(\mathrm{EC}_{2}\right)$. To measure the electrolyte leakage, a $\mathrm{pH} /$ conductivity meter (INCO-LAB Company, Al Kuwayt, Kuwait) was used, then the following equation for EL calculation was applied:

$$
\mathrm{EL}=(\mathrm{EC} 1 / \mathrm{EC} 2) \times 100
$$

To determine antioxidant activities, $0.5 \mathrm{~g}$ leaves were ground using a tissue grinder in $8 \mathrm{~mL}$ of cooled phosphate buffer ( $\mathrm{pH} 7.0$, containing $1 \%(\mathrm{w} / \mathrm{v})$ polyvinylpyrolidone) in test tubes. The homogenate was centrifuged at $15,000 \mathrm{rpm}$ for $20 \mathrm{~min}$ at $4{ }^{\circ} \mathrm{C}$. The supernatant was used for assays of enzymes activity. The activity of catalase (CAT) and peroxidase (POD) was measured by using the method of Maehly [18]. The reaction solution ( $3 \mathrm{~mL}$ ) contained $0.1 \mathrm{~mL}$ standard enzyme extract, $15 \mathrm{mM} \mathrm{H}_{2} \mathrm{O}_{2}$, and $50 \mathrm{mM}$ phosphate buffer (pH 7.0). The absorbance was taken at $240 \mathrm{~nm}$ with the spectrophotometer. The POD reaction solution $(3 \mathrm{~mL}$ ) contained $0.1 \mathrm{~mL}$ enzyme extract, $50 \mathrm{mM}$ sodium acetate buffer ( $\mathrm{pH}$ 5.0), $40 \mathrm{mM} \mathrm{H}_{2} \mathrm{O}_{2}$, and $20 \mathrm{mM}$ guaiacol. The absorbance was taken at $470 \mathrm{~nm}$. The superoxide dismutase (SOD) reaction solution $(3 \mathrm{~mL})$ contained $1.3 \mu \mathrm{M}$ riboflavin, $50 \mu \mathrm{L}$ enzyme extract, $50 \mu \mathrm{M}$ nitroblue tetrazolium (NBT dissolved in ethanol), $13 \mathrm{mM}$ methionine, $50 \mathrm{mM}$ phosphate buffer ( $\mathrm{pH} 7.8$ ), and $75 \mathrm{nM}$ EDTA [19]. The absorbance was taken at $240 \mathrm{~nm}$.

\subsection{Copper Concentration in Roots, Leaves and Stems}

To determine the $\mathrm{Cu}$ content, in root, leaves, and stems, respective parts from ten uniform randomly selected plants were taken, oven dried, and ground at 40 DAS. Briefly, $0.1 \mathrm{~g}$ of the respective ground sample was digested in $\mathrm{HNO}_{3} / \mathrm{HClO} 4$ (4:1) solution followed by dilution of digested sample in de-ionized water up to final volume of $25 \mathrm{ml}$. The supernatant was taken and passed through a filter paper. Copper standard solution (SRM$3114,10 \% \mathrm{HNO}_{3}$, Sigma-Aldrich, Milwaukee, WI, USA) was used as a primary calibration standard for the quantitative determination of copper in roots, leaves, and stem of pea. Readings were taken by using a Perkin-Elmer 3100 Atomic Absorption Spectrophotometer (Thermo Fisher Scientific, Lancashire, UK).

\subsection{Statistical Analysis}

A two-way analysis of variance ( $\mathrm{Cu}$ contamination of soil $\times \mathrm{GA}_{3}$ application) was executed to evaluate the effects of $\mathrm{GA}_{3}$ on the recorded variables both under normal 
(without $\mathrm{Cu}$ stress, control) and under $\mathrm{Cu}$-contaminated soil conditions. Tukey's honestly significance difference (HSD) test was used for comparison of treatment means $(p \leq 0.05)$, using a statistical software package 'Statistix 8.1' (https: / /www.statistix.com/). A principal component analysis among treatments and dependent variable was executed using XLSTAT ver. 2018 (https: / /www.xlstat.com/) to delineate the effect of different doses of $\mathrm{GA}_{3}$ on physiological growth attributes of pea plants grown in $\mathrm{Cu}-$ and $\mathrm{Cu}+$ soil. Clustering of observations and variables into groups were done on the basis of their highest squared cosine values corresponding to factors, F1 and F2. Correlation coefficients among variables were determined with Pearson $(n)$ method.

\section{Results}

\subsection{Plant Growth Attributes}

The results revealed that the untreated plants grown in $\mathrm{Cu}+$ soil exhibited the minimum plant height $(19.33 \mathrm{~cm})$ as compared to the other treatments. Though all foliar applied $\mathrm{GA}_{3}$ concentrations enhanced the plant height of pea, however, the plants treated with $100 \mathrm{mg} \cdot \mathrm{L}^{-1} \mathrm{GA}_{3}$ showed the maximum height in both soils $(40.1 \mathrm{~cm}$ in $\mathrm{Cu}-$ soil; $34.2 \mathrm{~cm}$ in $\mathrm{Cu}+$ soil). Similarly, maximum plant relative fresh weight $(34 \mathrm{~g})$ was recorded in plants receiving $100 \mathrm{mg} \cdot \mathrm{L}^{-1} \mathrm{GA}_{3}$ grown in $\mathrm{Cu}$ - soil followed by the plants receiving same treatment grown in $\mathrm{Cu}+$ soil, indicating that $\mathrm{GA}_{3}$ increased the above ground biomass accumulation in pea (Table 1).

Table 1. Plant growth attributes of pea plants as affected by soil $\mathrm{Cu}$ contamination and $\mathrm{GA}_{3}$ foliar application.

\begin{tabular}{|c|c|c|c|c|c|}
\hline \multicolumn{2}{|c|}{ Treatments } & \multirow{2}{*}{$\begin{array}{c}\text { Plant Height (cm) } \\
24.3 \pm 0.33^{\mathrm{e}}\end{array}$} & \multirow{2}{*}{$\begin{array}{c}\begin{array}{c}\text { Plant Relative Fresh } \\
\text { Weight (g) }\end{array} \\
20.6 \pm 0.38^{\text {ef }}\end{array}$} & \multirow{2}{*}{$\begin{array}{c}\text { Plant Dry Weight (g) } \\
9.0 \pm 0.23^{\mathrm{ef}}\end{array}$} & \multirow{2}{*}{$\begin{array}{c}\text { Leaves per Plant } \\
16.7 \pm 0.38^{\mathrm{e}}\end{array}$} \\
\hline \multirow{4}{*}{$\mathrm{Cu}-$ soil } & $0 \mathrm{mg} / \mathrm{L} \mathrm{GA}_{3}$ & & & & \\
\hline & $10 \mathrm{mg} / \mathrm{L} \mathrm{GA}_{3}$ & $27.3 \pm 0.57^{\mathrm{de}}$ & $22.1 \pm 0.25^{\mathrm{e}}$ & $11.3 \pm 0.65^{\mathrm{de}}$ & $18.3 \pm 0.12 \mathrm{de}$ \\
\hline & $50 \mathrm{mg} / \mathrm{L} \mathrm{GA}_{3}$ & $32.1 \pm 1.15^{b c}$ & $28.1 \pm 0.52^{c}$ & $14.4 \pm 0.16^{b c}$ & $24.5 \pm 0.54 \mathrm{bc}$ \\
\hline & $100 \mathrm{mg} / \mathrm{L} \mathrm{GA}_{3}$ & $40.1 \pm 1.13^{a}$ & $34 \pm 1.2^{\mathrm{a}}$ & $17.2 \pm 0.12^{a}$ & $30.1 \pm 0.82^{a}$ \\
\hline \multirow{4}{*}{$\mathrm{Cu}+$ soil } & $0 \mathrm{mg} / \mathrm{L} \mathrm{GA}_{3}$ & $19.3 \pm 0.88^{\mathrm{f}}$ & $18.1 \pm 0.57^{\mathrm{f}}$ & $8.0 \pm 0.54^{\mathrm{f}}$ & $13.7 \pm 0.23^{\mathrm{e}}$ \\
\hline & $10 \mathrm{mg} / \mathrm{L} \mathrm{GA}_{3}$ & $23.3 \pm 0.3^{\mathrm{e}}$ & $20.3 \pm 0.12$ ef & $9.7 \pm 0.43^{\text {def }}$ & $15.3 \pm 0.13^{\mathrm{e}}$ \\
\hline & $50 \mathrm{mg} / \mathrm{L} \mathrm{GA}_{3}$ & $28.7 \pm 0.33^{\mathrm{cd}}$ & $25.1 \pm 0.92^{d}$ & $12.3 \pm 0.27^{\mathrm{cd}}$ & $21.7 \pm 0.43^{\mathrm{cd}}$ \\
\hline & $100 \mathrm{mg} / \mathrm{L} \mathrm{GA}_{3}$ & $34.2 \pm 0.58^{b}$ & $31 \pm 1.12^{\mathrm{b}}$ & $15.2 \pm 0.74^{\mathrm{ab}}$ & $28.3 \pm 0.73^{a b}$ \\
\hline \multicolumn{2}{|c|}{$\mathrm{HSD}_{\text {(Interaction) }}$} & 3.773 & 2.614 & 2.669 & 4.76 \\
\hline
\end{tabular}

Different letters indicate significant difference among treatment means according to Tukey's honestly significant difference (HSD) test $(p \leq 0.05)$. Each value indicates mean of four replicates \pm standard error (5 plants per replicate under bi-factorial CRD arrangement).

In the case of plant dry weight, the plants treated with $100 \mathrm{mg} \cdot \mathrm{L}^{-1} \mathrm{GA}_{3}$ showed the highest values in both soils $(17.2 \mathrm{~g} \mathrm{Cu}-$ soil and $15.2 \mathrm{~g} \mathrm{Cu}+$ soil) followed by 50 and $10 \mathrm{mg} \cdot \mathrm{L}^{-1} \mathrm{GA}_{3}$ (Table 1). Similar to the aforesaid variables, plants treated with $\mathrm{GA}_{3}$ showed an increased number of leaves in a dose-dependent manner as compared to control. The plants treated with $100 \mathrm{mg} \cdot \mathrm{L}^{-1}$ showed the maximum number of leaves in both soils (30.1 Cu- soil and $28.3 \mathrm{Cu}+$ soil). The lowest values for plant height, fresh/dry weight, and number of leaves per plant were recorded in control followed by $10 \mathrm{mg} \cdot \mathrm{L}^{-1} \mathrm{GA}_{3}$ application in both $\mathrm{Cu}-$ and $\mathrm{Cu}+$ soil (Table 1).

\subsection{Physiological Variables}

The results shown in Figure 1 indicate that the plants grown in $\mathrm{Cu}-$ soil exhibited better physiological attributes as compared to those grown in $\mathrm{Cu}+$ soil. The exogenous application of $\mathrm{GA}_{3}$ improved the performance of pea in terms of their physiological attributes. Specifically, the plants treated with $100 \mathrm{mg} \cdot \mathrm{L}^{-1} \mathrm{GA}_{3}$ showed the highest chlorophyll content, photosynthetic rate, transpiration rate, and $\mathrm{CO}_{2}$ concentration (92.7 SPAD, $43 \mu \mathrm{mol}$ $\mathrm{CO}_{2} \mathrm{~m}^{-2} \cdot \mathrm{s}^{-1}, 2.2 \mathrm{mmol} \mathrm{H}_{2} \mathrm{O} \mathrm{m} \mathrm{m}^{-2} \cdot \mathrm{s}^{-1}$, and $167.1 \mu \mathrm{mol} \cdot \mathrm{mol}^{-1}$, respectively) followed by plants treated with $50 \mathrm{mg} \cdot \mathrm{L}^{-1} \mathrm{GA}_{3}\left(72.7 \mathrm{SPAD}, 32.6 \mu \mathrm{mol} \mathrm{CO} \mathrm{Cm}^{-2} \cdot \mathrm{s}^{-1}, 1.7 \mathrm{mmol}\right.$ $\mathrm{H}_{2} \mathrm{O} \mathrm{m}{ }^{-2} \cdot \mathrm{s}^{-1}$, and $142.3 \mu \mathrm{mol} \cdot \mathrm{mol}^{-1}$, respectively) and $10 \mathrm{mg} \cdot \mathrm{L}^{-1} \mathrm{GA}_{3}$ (47.5 SPAD, 
$25.3 \mu \mathrm{mol} \mathrm{CO} 2 \mathrm{~m}^{-2} \cdot \mathrm{s}^{-1}, 1.2 \mathrm{mmol} \mathrm{H} \mathrm{O} \mathrm{m}^{-2} \cdot \mathrm{s}^{-1}$, and $121 \mu \mathrm{mol} \cdot \mathrm{mol}^{-1}$, respectively) in $\mathrm{Cu}$ - soil. Similarly, the experimental units received foliar applied $100 \mathrm{mg} \cdot \mathrm{L}^{-1} \mathrm{GA}_{3}$ showed the highest chlorophyll contents, photosynthetic rate, transpiration rate, and $\mathrm{CO}_{2}$ concentration (70 SPAD, $39.3 \mu \mathrm{mol} \mathrm{CO} \mathrm{m}^{-2} \cdot \mathrm{s}^{-1}, 1.9 \mathrm{mmol} \mathrm{H} \mathrm{O} \mathrm{m}^{-2} \cdot \mathrm{s}^{-1}$, and $150 \mu \mathrm{mol} \cdot \mathrm{mol}^{-1}$, respectively) in $\mathrm{Cu}+$ soil. Whereas the untreated plants grown in $\mathrm{Cu}+$ soil showed minimum values of chlorophyll contents, photosynthetic rate, transpiration rate, and $\mathrm{CO}_{2}$ concentration (29 SPAD, $19 \mu \mathrm{mol} \mathrm{CO} 2 \mathrm{~m}^{-2} \cdot \mathrm{s}^{-1}, 0.8 \mathrm{mmol} \mathrm{H} \mathrm{O} \mathrm{m}^{-2} \cdot \mathrm{s}^{-1}$ and $86.63 \mu \mathrm{mol} \cdot \mathrm{mol}^{-1}$, respectively), showed the positive role of $\mathrm{GA}_{3}$ in improving physiological response of pea (Figure 1).
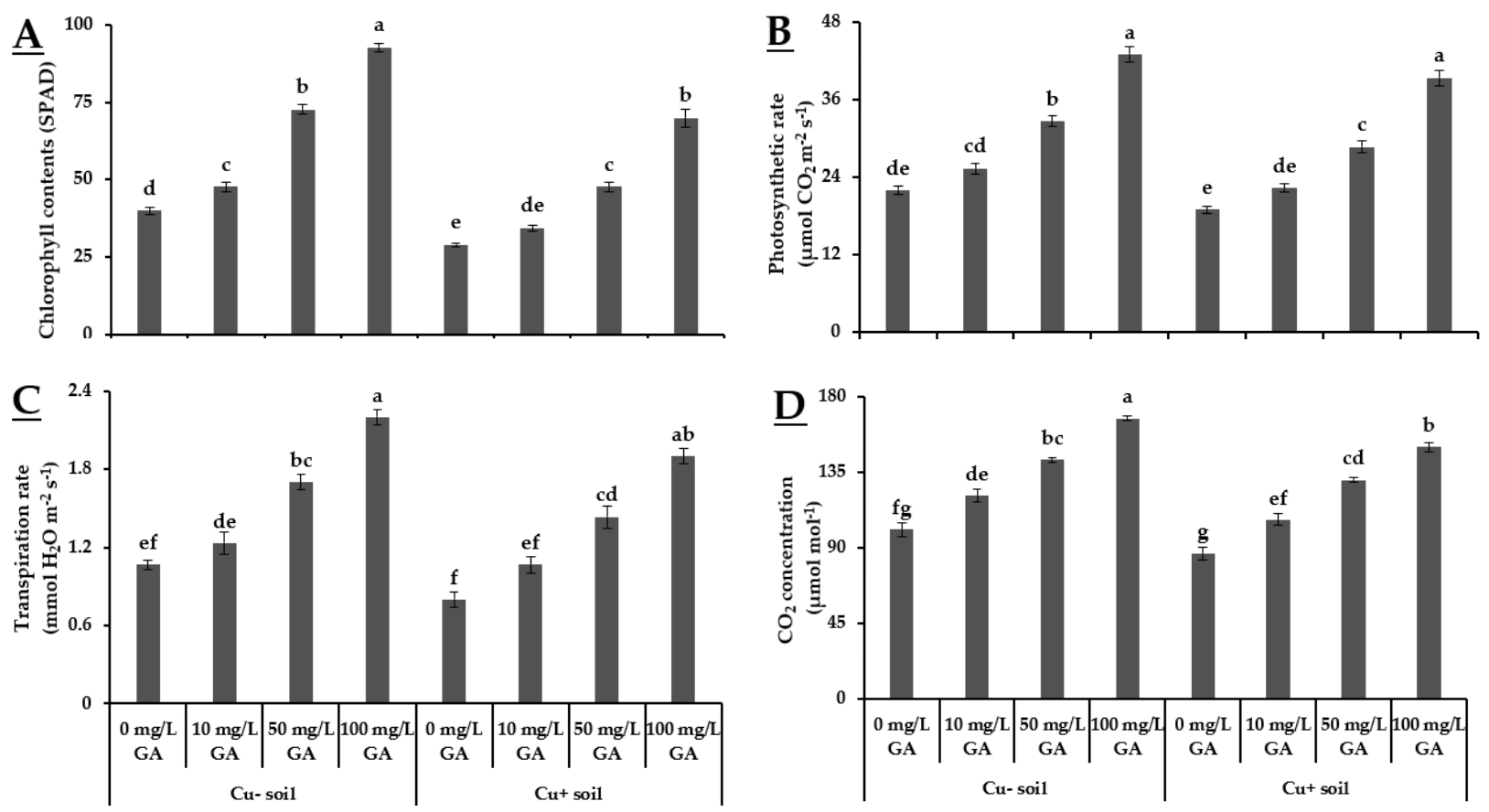

Figure 1. Effect of $\mathrm{GA}_{3}$ application on physiological variables of pea grown in $\mathrm{Cu}+$ and $\mathrm{Cu}-$ soil. (A) Chlorophyll contents; (B) Photosynthetic rate; (C) Transpiration rate; (D) $\mathrm{CO}_{2}$ concentration. Different letters indicate significant difference among treatment means according to Tukey's honestly significant difference (HSD) test $(p \leq 0.05)$. Vertical bars indicate mean \pm standard error ( $n=4,5$ plants per replicate under bi-factorial CRD arrangement).

\subsection{Oxidative Stress Indicators and Antioxidant Response}

Plants grown in $\mathrm{Cu}$ - soil, when treated with $100 \mathrm{mg} \cdot \mathrm{L}^{-1} \mathrm{GA}_{3}$, showed minimum MDA and $\mathrm{H}_{2} \mathrm{O}_{2}$ contents and electrolyte leakage $\left(23 \mu \mathrm{mol} \cdot \mathrm{g}^{-1}, 143.32 \mu \mathrm{mol} \cdot \mathrm{g}^{-1}\right.$, and $27.2 \%$, respectively). The plants grown in $\mathrm{Cu}+$ soil exhibited increased electrolyte leakage, MDA, and $\mathrm{H}_{2} \mathrm{O}_{2}$ contents than those were grown in $\mathrm{Cu}$ - soil. The exogenous application of $\mathrm{GA}_{3}$ significantly reduced electrolyte leakage, MDA, and $\mathrm{H}_{2} \mathrm{O}_{2}$ contents in a concentrationdependent manner. The maximum decrease in $\mathrm{MDA}, \mathrm{H}_{2} \mathrm{O}_{2}$, and electrolyte leakage were observed in plants treated with $100 \mathrm{mg} \cdot \mathrm{L}^{-1} \mathrm{GA}_{3}$ in $\mathrm{Cu}-(63.29 \%, 63.40 \%$, and $62.84 \%$, respectively) and $\mathrm{Cu}+$ soils $(54.12 \%, 58.79 \%$, and $57.66 \%$, respectively) as compared to other experimental units and control (Figure 2). 

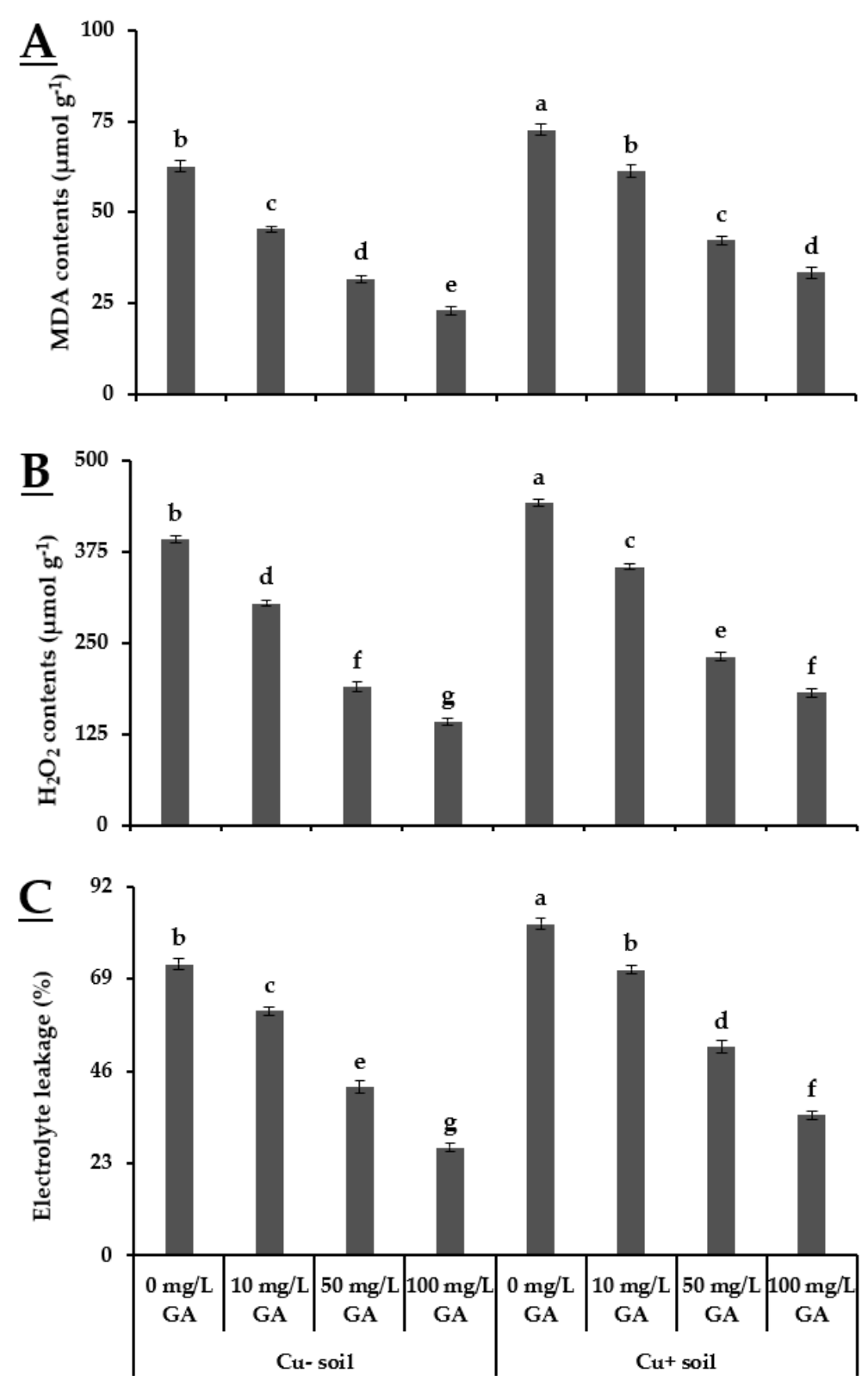

Figure 2. Effect of $\mathrm{GA}_{3}$ application on malondialdehyde (MDA), $\mathrm{H}_{2} \mathrm{O}_{2}$, and electrolyte leakage of leaves of pea grown in $\mathrm{Cu}+$ and $\mathrm{Cu}$ - soils. (A) Malondialdehyde contents; (B) $\mathrm{H}_{2} \mathrm{O}_{2}$ contents; (C) Electrolyte leakage. Different letters indicate significant difference among treatment means according to Tukey's honestly significant difference (HSD) test $(p \leq 0.05)$. Vertical bars indicate mean \pm standard error $(n=4,5$ plants per replicate under bi-factorial CRD arrangement).

The exogenous application of $100 \mathrm{mg} \cdot \mathrm{L}^{-1} \mathrm{GA}_{3}$ exhibited maximum SOD activity in the plants grown in $\mathrm{Cu}-$ soil $\left(75 \mathrm{U} \cdot \mathrm{g}^{-1} \cdot \mathrm{FW}\right)$ followed by the plants grown in $\mathrm{Cu}+$ soil $\left(64.39 \mathrm{U} \cdot \mathrm{g}^{-1} \cdot \mathrm{FW}\right)$. In similarity with the aforementioned variable, the highest POD activity $\left(136.21 \mathrm{U} \cdot \mathrm{g}^{-1} \cdot \mathrm{FW}\right)$ was also observed in pea plants grown in $\mathrm{Cu}$ - soil treated with $100 \mathrm{mg} \cdot \mathrm{L}^{-1} \mathrm{GA}_{3}$. Plants receiving foliar application of $50 \mathrm{mg} \cdot \mathrm{L}^{-1} \mathrm{GA}_{3}$ also showed better performance in both soil conditions. In the case of CAT activity, maximum value $\left(245 \mathrm{U} \cdot \mathrm{g}^{-1} \cdot \mathrm{FW}\right)$ was also recorded in plants treated with $100 \mathrm{mg} \cdot \mathrm{L}^{-1} \mathrm{GA}_{3}$ in $\mathrm{Cu}-$ soil. The reduced activity of antioxidants i.e., $\mathrm{SOD}, \mathrm{POD}$, and $\mathrm{CAT}$ in untreated plants grown in $\mathrm{Cu}+$ soil indicates a significant effect of $\mathrm{Cu}$ stress on pea plants (Figure 3). 

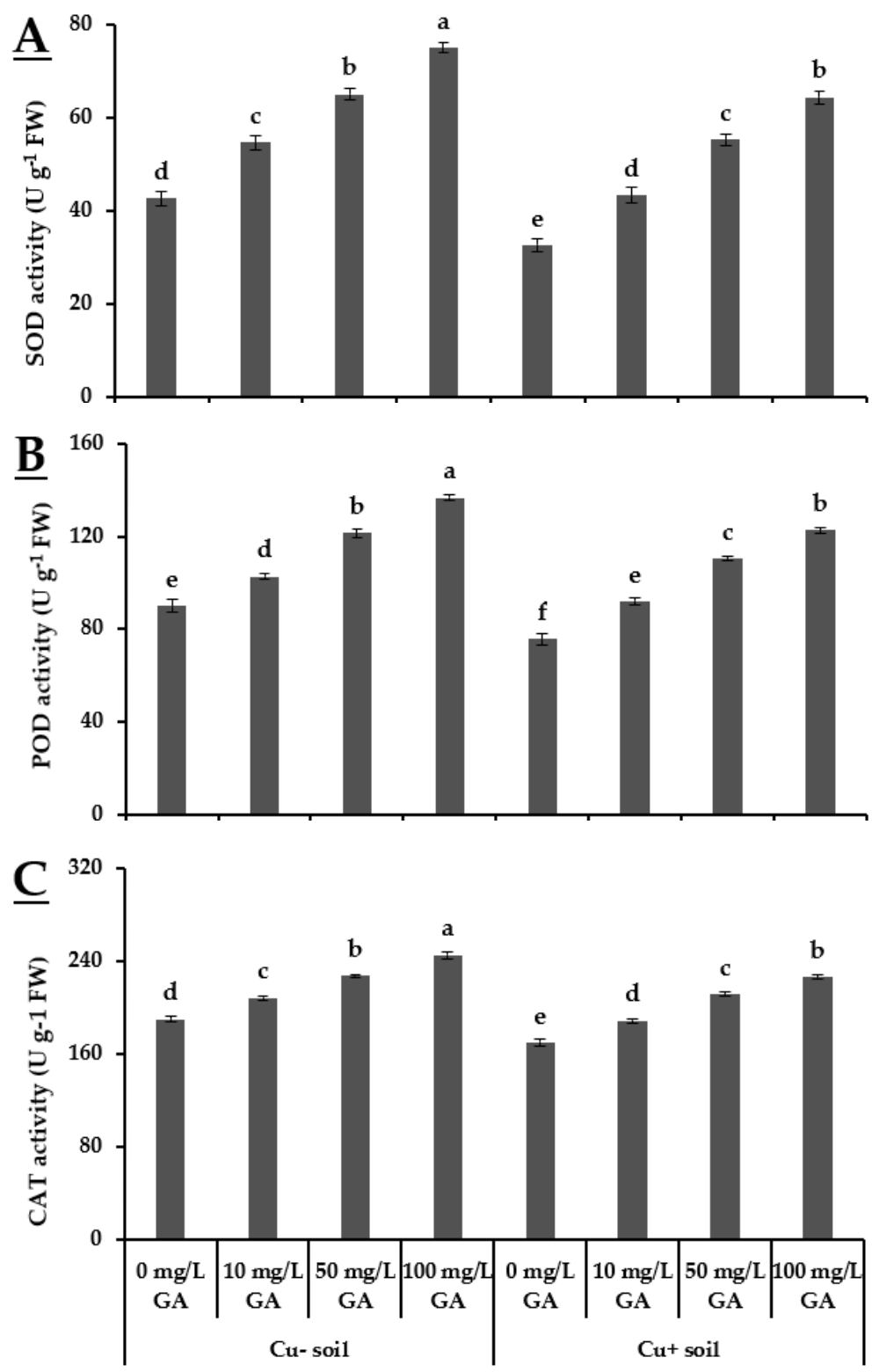

Figure 3. Effect of $\mathrm{GA}_{3}$ on activity of reactive oxygen species (superoxide dismutase (SOD), peroxidase (POD), catalase (CAT)) of peas grown in $\mathrm{Cu}+$ and $\mathrm{Cu}-$ soils. (A) SOD activity; (B) POD activity; (C) CAT activity. Different letters indicate significant difference among treatment means according to Tukey's honestly significant difference (HSD) test $(p \leq 0.05)$. Vertical bars indicate mean \pm standard error ( $n=4,5$ plants per replicate under bi-factorial CRD arrangement).

\subsection{Cu Concentration in Roots, Leaves and Stem}

The $\mathrm{GA}_{3}$-untreated plants grown in $\mathrm{Cu}$ - soil exhibited minimum $\mathrm{Cu}$ concentration in roots, leaves, and stem of pea plants $\left(16.66,31.66\right.$ and $22.12 \mathrm{mg} \cdot \mathrm{kg}^{-1}$, respectively) as compared to all other treatments. The foliar application of $\mathrm{GA}_{3}$ enhanced the uptake of $\mathrm{Cu}$ in plants. The plants grown in $\mathrm{Cu}+$ soil showed more $\mathrm{Cu}$ concentration in roots, leaves, and stem as compared to those grown in $\mathrm{Cu}$ - soil. The plants treated with $100 \mathrm{mg} \cdot \mathrm{L}^{-1} \mathrm{GA}_{3}$ showed maximum $\mathrm{Cu}$ concentration in roots, leaves, and stem of peas grown in both soils $\left(34.66,58.05\right.$ and $39.66 \mathrm{mg} \cdot \mathrm{kg}^{-1}{ }^{\prime} \mathrm{Cu}-\mathrm{soil}^{\prime} ; 90.66,193.31$ and $145.26 \mathrm{mg} \cdot \mathrm{kg}^{-1}{ }^{\prime} \mathrm{Cu}+\mathrm{soil}$ ', respectively) (Table 2). 
Table 2. Copper concentration in roots, stem, and leaves of peas as affected by exogenous application of $\mathrm{GA}_{3}$ and $\mathrm{Cu}$ contamination of soil.

\begin{tabular}{|c|c|c|c|c|}
\hline \multicolumn{2}{|c|}{ Treatments } & $\begin{array}{l}\text { Root Cu } \\
\left(\mathrm{mg} \cdot \mathrm{kg}^{-1}\right)\end{array}$ & $\begin{array}{l}\text { Leaves Cu } \\
\left(\mathrm{mg} \cdot \mathrm{kg}^{-1}\right)\end{array}$ & $\begin{array}{l}\text { Stem Cu } \\
\left(\mathrm{mg} \cdot \mathrm{kg}^{-1}\right)\end{array}$ \\
\hline \multirow{4}{*}{$\mathrm{Cu}-$ soil } & $0 \mathrm{mg} / \mathrm{L} \mathrm{GA}_{3}$ & $16.7 \pm 0.81 \mathrm{~g}$ & $31.7 \pm 0.88^{h}$ & $22.1 \pm 0.52 \mathrm{~g}$ \\
\hline & $10 \mathrm{mg} / \mathrm{L} \mathrm{GA}_{3}$ & $20.7 \pm 0.78^{g}$ & $36.0 \pm 1.15 \mathrm{~g}$ & $27.2 \pm 0.57^{\mathrm{fg}}$ \\
\hline & $50 \mathrm{mg} / \mathrm{L} \mathrm{GA}_{3}$ & $26.3 \pm 0.88^{f}$ & $43.7 \pm 1.76^{\mathrm{f}}$ & $32.7 \pm 0.72^{f}$ \\
\hline & $100 \mathrm{mg} / \mathrm{L} \mathrm{GA}_{3}$ & $34.7 \pm 1.25^{\mathrm{e}}$ & $58.1 \pm 1.52^{\mathrm{e}}$ & $39.7 \pm 0.89 \mathrm{e}$ \\
\hline \multirow{4}{*}{$\mathrm{Cu}+$ soil } & $0 \mathrm{mg} / \mathrm{L} \mathrm{GA}_{3}$ & $61.3 \pm 0.69^{d}$ & $145.2 \pm 2.31^{d}$ & $82.7 \pm 1.45^{\mathrm{d}}$ \\
\hline & $10 \mathrm{mg} / \mathrm{L} \mathrm{GA}_{3}$ & $66.7 \pm 0.89^{c}$ & $161.9 \pm 1.15^{c}$ & $95.3 \pm 0.88^{c}$ \\
\hline & $50 \mathrm{mg} / \mathrm{L} \mathrm{GA}_{3}$ & $74.3 \pm 0.82^{b}$ & $177.3 \pm 1.73^{b}$ & $119.9 \pm 2.3^{b}$ \\
\hline & $100 \mathrm{mg} / \mathrm{L} \mathrm{GA}_{3}$ & $90.7 \pm 1.2^{\mathrm{a}}$ & $193.3 \pm 1.85^{a}$ & $145.3 \pm 2.33^{a}$ \\
\hline \multicolumn{2}{|c|}{$\mathrm{HSD}_{\text {(Interaction) }}$} & 4.371 & 3.527 & 6.332 \\
\hline
\end{tabular}

Different letters indicate significant difference among treatment means according to Tukey's honestly significant difference (HSD) test $(p \leq 0.05)$. Each value indicates mean of four replicates \pm standard error (10 plants per replicate under bi-factorial CRD arrangement).

\subsection{Multivariate Analysis}

Factor F1, having eigenvalue 13.711 and variability of $80.65 \%$ showed positive correlation among plant height, biomass accumulation, photosynthetic rate, transpiration rate, $\mathrm{CO}_{2}$ index, $\mathrm{H}_{2} \mathrm{O}_{2}$ contents, SOD, $\mathrm{POD}$, and CAT activity with 50 and $100 \mathrm{mg} \cdot \mathrm{L}^{-1} \mathrm{GA}_{3}$ treatment in plant grown in $\mathrm{Cu}-$ soil, as well as $100 \mathrm{mg} \cdot \mathrm{L}^{-1} \mathrm{GA}_{3}$ treatment in plant grown in $\mathrm{Cu}+$ soil. Malondialdehyde, electrolyte leakage, and $\mathrm{H}_{2} \mathrm{O}_{2}$ contents are shown in the negative side of the $\mathrm{F} 1$ axis, indicating their negative correlation with $100 \mathrm{mg} \cdot \mathrm{L}^{-1} \mathrm{GA}_{3}$ and positive correlation with control (no GA 3 treatment) (Table 3) (Figure 4).

Table 3. Correlation coefficients among variables and principal components factors.

\begin{tabular}{ccc}
\hline \multirow{2}{*}{ Variables } & \multicolumn{2}{c}{ Principle Component Factors } \\
\cline { 2 - 3 } & F1 & F2 \\
\hline Plant height & 0.992 & -0.056 \\
Plant relative fresh weight & 0.989 & 0.082 \\
Plant dry weight & 0.997 & 0.025 \\
Number of leaves & 0.986 & 0.091 \\
Chlorophyll content & 0.974 & -0.148 \\
Photosynthetic rate & 0.982 & 0.105 \\
Transpiration rate & 0.995 & 0.033 \\
CO ${ }_{2}$ index & 0.997 & 0.026 \\
Malondialdehyde content & -0.983 & 0.056 \\
H2 ${ }_{2}$ content & -0.979 & -0.087 \\
Electrolyte leakage & -0.997 & -0.059 \\
Superoxide dismutase & 0.989 & -0.094 \\
Peroxidase & 0.996 & -0.022 \\
Catalase & 0.990 & -0.098 \\
Root Cu content & 0.027 & 0.998 \\
Leaves Cu content & -0.102 & 0.992 \\
Stem Cu content & 0.042 & 0.995 \\
Eigenvalue & 13.711 & 3.059 \\
Explained variability $(\%)$ & 80.652 & 17.997 \\
\hline
\end{tabular}

Second factor F2, having eigenvalue 3.059 and variability of $17.99 \%$ represented $\mathrm{Cu}$ contents in leaves, roots, and stems. Cu contents in leaves, roots, and stem are shown in the positive half of $\mathrm{F} 2$ depict their positive correlation with $50 \mathrm{mg} \cdot \mathrm{L}^{-1} \mathrm{GA}_{3}$ treatment on plants grown in $\mathrm{Cu}+$ soil, while negative correlation with $10 \mathrm{mg} \cdot \mathrm{L}^{-1} \mathrm{GA}_{3}$ treatment on plants grown in $\mathrm{Cu}$ - soil. Thus, principal component analysis delineated the morphologi- 
cal, physiological, and oxidative response of pea plants under the influence of $\mathrm{GA}_{3}$ and $\mathrm{Cu}$ toxicity.

Biplot (axes F1 and F2: $98.65 \%$ )

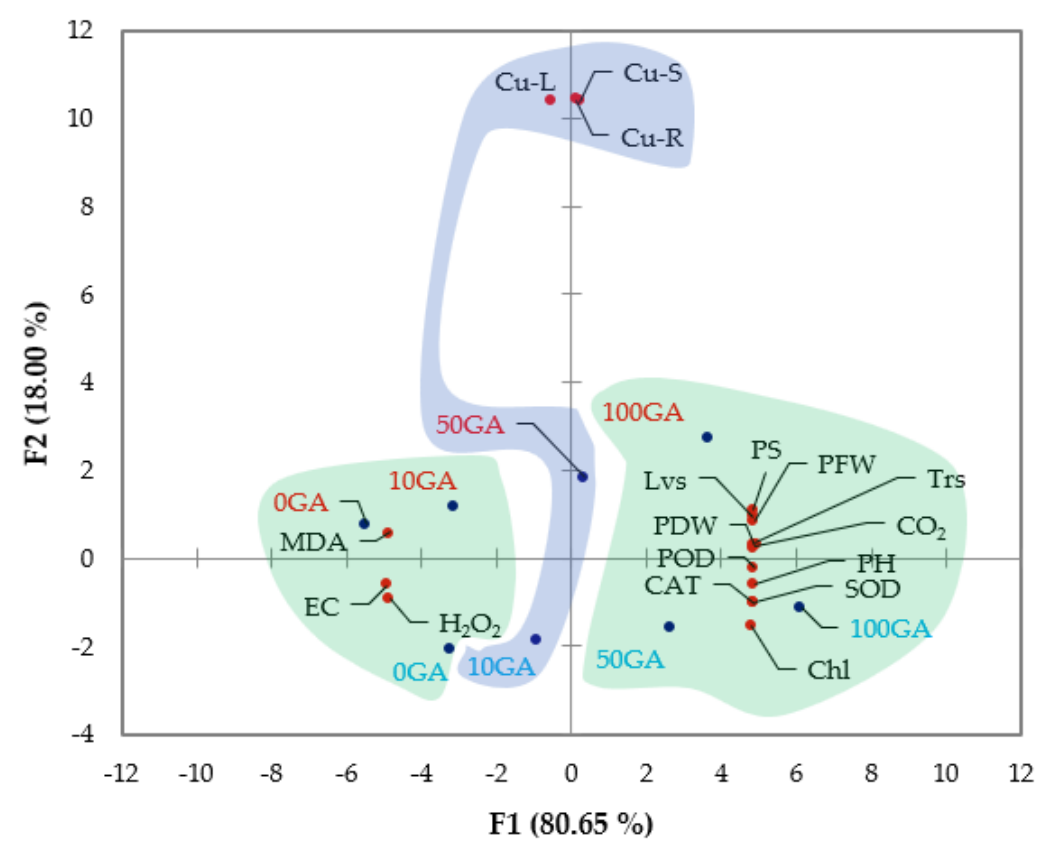

Figure 4. Principal component analysis (biplot) among observations (treatments) and variables (morphological, physiological, and oxidative attributes) of peas. Blue and red colored text depicts $\mathrm{GA}_{3}$ treatments on plants grown in $\mathrm{Cu}-$ and $\mathrm{Cu}+$, respectively. Clustering of observations and variables into groups (colored shading) is based on their highest squared cosine values corresponding to the factor, F1 (green) and F2 (blue). Abbreviations: 0GA-no GA 3 treatment; 10GA-10 mg. $\mathrm{L}^{-1}$ $\mathrm{GA}_{3} ; 50 \mathrm{GA}-50 \mathrm{mg} \cdot \mathrm{L}^{-1} \mathrm{GA}_{3} ; 100 \mathrm{GA}-100 \mathrm{mg} \cdot \mathrm{L}^{-1} \mathrm{GA}_{3} ; \mathrm{PH}$-Plant Height; PFW—Plant Relative Fresh Weight; PDW—Plant Dry Weight; Lvs_-Number of Leaves; Chl—Chlorophyll Content; PSPhotosynthetic Rate; Trs-Transpiration Rate; $\mathrm{CO}_{2}-\mathrm{CO}_{2}$ Index; $\mathrm{MDA}-$ Malondialdehyde Content; $\mathrm{H}_{2} \mathrm{O}_{2}-\mathrm{H}_{2} \mathrm{O}_{2}$ content; EC-Electrolyte Leakage; SOD-Superoxide Dismutase; —Peroxidase; CATCatalase; $\mathrm{Cu}-\mathrm{R}$-Root $\mathrm{Cu}$ Content; $\mathrm{Cu}-\mathrm{L}$-Leaf Cu Content; $\mathrm{Cu}-\mathrm{S}$-Stem Cu Content.

\section{Discussion}

Several studies have shown that $\mathrm{Cu}$ toxicity severely influences growth and productivity of leguminous crops [20-22]. In the present study, the pea plants grown in $\mathrm{Cu}+$ soil showed reduced growth and biomass accumulation as compared to the plants grown in $\mathrm{Cu}-$ soil (Table 1). Our results are consistent with those of Massoud et al. [23], who reported that the $\mathrm{Cu}$ toxicity reduced the fresh biomass of pea plants. The exogenous application of phytohormones is considered a way to mitigate the toxic effects of heavy metals and increase plant tolerance to some abiotic stressors [24]. In our experiment, the foliar applied $\mathrm{GA}_{3}$ alleviated the toxic effect of $\mathrm{Cu}$ and enhanced plant height, number of leaves, and biomass accumulation in pea plants grown in both $\mathrm{Cu}+$ and $\mathrm{Cu}-$ soil (Table 1). These findings are in line with other studies that reported the remarkable role of exogenous application of $\mathrm{GA}_{3}$ to enhance plant growth and tolerance to heavy metals such as Cd [25-27]. In accordance with our study, the exogenous application of $100 \mathrm{mg} \cdot \mathrm{L}^{-1} \mathrm{GA}_{3}$ enhanced shoot fresh and dry weight of jute under $\mathrm{Cu}$ stress [4]. In the present study, enhanced plant growth variables with the exogenous application of $\mathrm{GA}_{3}$ in $\mathrm{Cu}$-stressed plants might be due to better gaseous exchange attributes [4], or GA3 helps in decreasing free metal ions in plants as suggested by Shafigh et al. [28].

Gibberellins stimulate plant growth and alleviate the inhibitory effects of different abiotic stressors on plant physiological and growth attributes, such as plant biomass accumulation, chlorophyll, minerals accumulation, gas exchange, electrolyte leakage, as well as 
the activity of reactive oxygen species [29-31]. According to Lüttge [32], photosynthetic efficiency of plants depends on chlorophyll content, which plays a key role in light dependent reaction of photosynthesis. Previous literature also stated that increased production of antioxidants in chloroplast resulted in scavenging of ROS and curtail oxidative damage to photosynthetic membranes [4]. Our findings revealed that chlorophyll content and gas exchanges were significantly influenced by the exogenous application of $\mathrm{GA}_{3}$ (Figure 1). Though all $\mathrm{GA}_{3}$ concentrations applied improved the physiological attributes in both $\mathrm{Cu}+$ and $\mathrm{Cu}$ - soil, higher values were observed in experimental units received $100 \mathrm{mg} \cdot \mathrm{L}^{-1}$ $\mathrm{GA}_{3}$. The chlorophyll content and gaseous exchange attributes were reduced in $\mathrm{Cu}+$ soil as compared to $\mathrm{Cu}-$ soil (Figure 1). The reason behind this phenomenon might be the structural damage of chloroplast resulted from $\mathrm{Cu}$ exposure in the soil system [33]. Structural damage to chloroplast imparted negative influence on the photosynthetic efficiency due to damaged thylakoids which resulted in lower chlorophyll contents [34]. Nevertheless, exogenous application of $\mathrm{GA}_{3}$ as foliar spray significantly buffered these negative effects in $\mathrm{Cu}$-stressed plants. Previous literature also stated the protective role $\mathrm{GA}_{3}$ toward the photosynthetic machinery in metal contaminated soil [10]. The possible reason behind this mechanism might be the enhanced antioxidant activities that reduced the $\mathrm{Cu}$-induced oxidative damages [35]. The decreased photosynthetic performances of plants without $\mathrm{GA}_{3}$ application may be linked to $\mathrm{Cu}$ toxicity and findings support the observation of Habiba et al. [36] who claimed that $\mathrm{Cu}$ toxicity caused a decline in chlorophyll biosynthesis and increased damage of thylakoid membranes.

Copper stress rigorously impeded the performance of crop plants [37]. In addition, $\mathrm{Cu}$ stress promoted oxidative damage as inferred from the enhanced production of ROS. Increased synthesis of ROS and accumulation in plant tissues cause damage to cellular structures and macromolecules such as nucleic acid, proteins, lipids, and the photosynthetic apparatus [38]. However, it has been reported that increased synthesis of antioxidant enzymes such as SOD, POD, and CAT improved the response of Oryza sativa [39] and Brassica napus [40] plants under $\mathrm{Cu}$ stress. Accordingly, in the present study, the alleviation of oxidative stress resulted from enhanced antioxidant activities. The findings of our study also highlight the effectiveness of foliar applied $\mathrm{GA}_{3}$ in both $\mathrm{Cu}+$ and $\mathrm{Cu}-$ soils. Foliar application of $\mathrm{GA}_{3}\left(100 \mathrm{mg} \cdot \mathrm{L}^{-1}\right)$ decreased the production of $\mathrm{MDA}, \mathrm{H}_{2} \mathrm{O}_{2}$ contents, and electrolyte leakage compared to control (no $\mathrm{GA}_{3}$ application). In contrast, all concentrations of foliar applied $\mathrm{GA}_{3}$ enhanced the activities of SOD, POD, and CAT, but higher values for antioxidants enzymes were linked with $100 \mathrm{mg} \cdot \mathrm{L}^{-1} \mathrm{GA}_{3}$ (Figures 2 and 3). The enhanced antioxidants activity can be considered as an indication of decreased accumulation of MDA and $\mathrm{H}_{2} \mathrm{O}_{2}$ contents $[4,33,41]$. These findings are supported by the results of Saleem et al. [4] who reported a similar effect of foliar applied $\mathrm{GA}_{3}$ to ameliorate the oxidative stress response in Corchorus capsularis L. Moreover, upregulation of activity of various antioxidant enzymes such as SOD, POD, and CAT shows the higher capacity of plants to scavenge excessive ROS under $\mathrm{Cu}$ stress [4]. The results of the current study are also in line with Fahad et al. [42], who argued that when the scavenging system against ROS is not effective, then crop plants become vulnerable to oxidative damages.

Depending on growth conditions, plants vary in their capacity of $\mathrm{Cu}$ uptake and accumulation. Plant roots play a central role in $\mathrm{Cu}$ uptake and transfer to stem and leaves through the xylem $[43,44]$. Pea plants treated with $\mathrm{GA}_{3}$ exhibited enhanced $\mathrm{Cu}$ accumulation in roots, leaves, and stem under $\mathrm{Cu}$ stress (Table 2). The increased gaseous exchange attributes such as photosynthesis and transpiration rate as the result of exogenous application of $\mathrm{GA}_{3}$ was likely the reason behind the increased $\mathrm{Cu}$ uptake by plants, even under phytotoxicity conditions $[4,36]$. The efficacy of $\mathrm{GA}_{3}$ to modulate the plant physiological status depends on its concentration, application method, and plant genetics [4]. The results of the present study also showed that the response of pea plants growth and development to $\mathrm{GA}_{3}$ application changed with change in concentration, mostly under $\mathrm{Cu}$ stressing conditions, overall, suggesting that $\mathrm{GA}_{3}$ promoted growth of pea plants and alleviated the 
$\mathrm{Cu}$ toxicity. To this end, foliar application of $100 \mathrm{mg} \cdot \mathrm{L}^{-1}$ induced the best response in pea plants in terms morphological, physiological, and oxidative attributes.

\section{Conclusions}

Gibberellic acid is a key regulator of several stages of plant growth, development, physiology, and morphology in plants, showing also pivotal regulatory effects against various environmental stressors. In this study, foliar application with different concentrations of $\mathrm{GA}_{3}$ proved to be successful for enhancing tolerance to $\mathrm{Cu}$ stress in pea plants, as evidenced from higher plant growth and antioxidant activity. In this view, the foliar application of a $100 \mathrm{mg} \cdot \mathrm{L}^{-1} \mathrm{GA}_{3}$ solution proved to be the most effective in enhancing tolerance to $\mathrm{Cu}$ and related oxidative stresses in pea plants, while at the same time maximizing the $\mathrm{Cu}$ content in plant organs. Results also reveal that GA3 alleviated $\mathrm{Cu}$-induced stress on pea plants by stimulated activities of reactive oxygen-scavenging enzymes catalase, peroxidase, and superoxide dismutase, which not only helped in reducing electrolyte leakage, but also hindered accumulation of MDA and $\mathrm{H}_{2} \mathrm{O}_{2}$ in $\mathrm{Cu}$-stressed pea plants. Overall, this indicates the possible role of this plant hormone in sustaining the phytoextraction functions of this important, $\mathrm{N}$-fixing leguminous species, when crop rotations in $\mathrm{Cu}$-polluted soils are concerned.

Author Contributions: Conceptualization, T.J., M.M.A. and R.P.M.; methodology, T.J., M.M.A. and R.S.; validation, R.A., I.A. and R.P.M.; formal analysis T.J., R.S. and R.P.M.; investigation T.J. and M.M.A.; data curation, R.S., I.A. and R.P.M.; writing-original draft preparation T.J. and R.P.M.; writing-review and editing T.J., I.A. and R.P.M.; supervision, T.J. and M.M.A. All authors have read and agreed to the published version of the manuscript.

Funding: This research received no external funding.

Institutional Review Board Statement: Not applicable.

Informed Consent Statement: Not applicable.

Data Availability Statement: Data sharing not applicable.

Acknowledgments: The authors thank valuable contributions for data collection provided by Ahmed Mukhtar. Helpful suggestions were provided by Shah Fahad and Saddam Hussain for data analysis.

Conflicts of Interest: The authors declare no conflict of interest.

\section{References}

1. FAOSTAT. World Food and Agriculture 2018: Statistical Pocketbook; FAO: Rome, Italy, 2018.

2. Davies, P.J.; Muehlbauer, F.J. The Physiology of Vegetable Crops, 2nd ed.; CABI: Wallingford, UK, 2020.

3. Slima, D.F.; Ahmed, D.A.E.-A. Trace Metals Accumulated in Pea Plant (Pisum sativum L.) as a Result of Irrigation with Wastewater. J. Soil Sci. Plant Nutr. 2020, 20, 2749-2760. [CrossRef]

4. Saleem, M.H.; Fahad, S.; Adnan, M.; Ali, M.; Rana, M.S.; Kamran, M.; Ali, Q.; Hashem, I.A.; Bhantana, P.; Ali, M.; et al. Foliar application of gibberellic acid endorsed phytoextraction of copper and alleviates oxidative stress in jute (Corchorus capsularis L.) plant grown in highly copper-contaminated soil of China. Environ. Sci. Pollut. Res. 2020, 27, 37121-37133. [CrossRef] [PubMed]

5. Allevato, E.; Mauro, R.P.; Stazi, S.R.; Marabottini, R.; Leonardi, C.; Ierna, A.; Giuffrida, F. Arsenic accumulation in grafted melon plants: Role of rootstock in modulating root-to-shoot translocation and physiological response. Agronomy 2019, 9, 828. [CrossRef]

6. Vardhan, K.H.; Kumar, P.S.; Panda, R.C. A review on heavy metal pollution, toxicity and remedial measures: Current trends and future perspectives. J. Mol. Liq. 2019, 290, 111197. [CrossRef]

7. Fahad, S.; Rehman, A.; Shahzad, B.; Tanveer, M.; Saud, S.; Kamran, M.; Ihtisham, M.; Khan, S.U.; Turan, V.; ur Rahman, M.H. Rice Responses and Tolerance to Metal/Metalloid Toxicity. In Advances in Rice Research for Abiotic Stress Tolerance; Elsevier: Amsterdam, The Netherlands, 2019; pp. 299-312.

8. Ullah, A.; Heng, S.; Munis, M.F.H.; Fahad, S.; Yang, X. Phytoremediation of heavy metals assisted by plant growth promoting (PGP) bacteria: A review. Environ. Exp. Bot. 2015, 117, 28-40. [CrossRef]

9. Fahad, S.; Hussain, S.; Bano, A.; Saud, S.; Hassan, S.; Shan, D.; Khan, F.A.; Khan, F.; Chen, Y.; Wu, C.; et al. Potential role of phytohormones and plant growth-promoting rhizobacteria in abiotic stresses: Consequences for changing environment. Environ. Sci. Pollut. Res. 2015, 22, 4907-4921. [CrossRef]

10. Saleem, M.; Asghar, H.N.; Khan, M.Y.; Zahir, Z.A. Gibberellic acid in combination with pressmud enhances the growth of sunflower and stabilizes chromium(VI)-contaminated soil. Environ. Sci. Pollut. Res. 2015, 22, 10610-10617. [CrossRef] 
11. Ullah, S.; Anwar, S.; Rehman, M.; Khan, S.; Zafar, S.; Liu, L.; Peng, D. Interactive effect of gibberellic acid and NPK fertilizer combinations on ramie yield and bast fibre quality. Sci. Rep. 2017, 7, 10647. [CrossRef]

12. UZAL, O.; Yasar, F. Effects of GA3 hormone treatments on ion uptake and growth of pepper plants under cadmium stress. Appl. Ecol. Environ. Res. 2017, 15, 1347-1357. [CrossRef]

13. Ji, P.; Tang, X.; Jiang, Y.; Tong, Y.; Gao, P.; Han, W. Potential of gibberellic acid 3 (GA3) for enhancing the phytoremediation efficiency of Solanum nigrum L. Bull. Environ. Contam. Toxicol. 2015, 95, 810-814. [CrossRef] [PubMed]

14. Hadi, F.; Bano, A.; Fuller, M.P. The improved phytoextraction of lead (Pb) and the growth of maize (Zea mays L.): The role of plant growth regulators (GA3 and IAA) and EDTA alone and in combinations. Chemosphere 2010, 80, 457-462. [CrossRef]

15. Sun, Y.; Xu, Y.; Zhou, Q.; Wang, L.; Lin, D.; Liang, X. The potential of gibberellic acid 3 (GA3) and Tween-80 induced phytoremediation of co-contamination of $\mathrm{Cd}$ and Benzo[a]pyrene (B[a]P) using Tagetes patula. J. Environ. Manag. 2013, 114, 202-208. [CrossRef]

16. Isogai, S.; Touno, K.; Shimomura, K. Gibberellic acid improved shoot multiplication in Cephaelis ipecacuanha. Vitr. Cell. Dev. Biol. Plant 2008, 44, 216-220. [CrossRef]

17. Heath, R.L.; Packer, L. Photoperoxidation in isolated chloroplasts: I. Kinetics and stoichiometry of fatty acid peroxidation. Arch. Biochem. Biophys. 1968, 125, 189-198. [CrossRef]

18. Maehly, A.C. The Assay of Catalases and Peroxidases. In Methods of Biochemical Analysis; Wiley: Hoboken, NJ, USA, 2006; pp. 357-424.

19. Giannopolitis, C.N.; Ries, S.K. Superoxide Dismutases. Plant Physiol. 1977, 59, 309-314. [CrossRef] [PubMed]

20. Sfaxi-Bousbih, A.; Chaoui, A.; El Ferjani, E. Unsuitable availability of nutrients in germinating bean embryos exposed to copper excess. Biol. Trace Elem. Res. 2010, 135, 295-303. [CrossRef] [PubMed]

21. Karmous, I.; Khadija, J.; Chaoui, A.; El Ferjani, E. Proteolytic activities in Phaseolus vulgaris cotyledons under copper stress. Physiol. Mol. Biol. Plants 2012, 18, 337-343. [CrossRef]

22. Chaoui, A.; El Ferjani, E. $\beta$-Estradiol protects embryo growth from heavy-metal toxicity in germinating lentil seeds. J. Plant Growth Regul. 2013, 32, 636-645. [CrossRef]

23. Ben Massoud, M.; Karmous, I.; El Ferjani, E.; Chaoui, A. Alleviation of copper toxicity in germinating pea seeds by IAA, GA 3, Ca and citric acid. J. Plant Interact. 2018, 13, 21-29. [CrossRef]

24. Piotrowska-Niczyporuk, A.; Bajguz, A.; Zambrzycka, E.; Godlewska-Żyłkiewicz, B. Phytohormones as regulators of heavy metal biosorption and toxicity in green alga Chlorella vulgaris (Chlorophyceae). Plant Physiol. Biochem. 2012, 52, 52-65. [CrossRef] [PubMed]

25. Wang, C.Q.; Song, H. Calcium protects Trifolium repens L. seedlings against cadmium stress. Plant Cell Rep. 2009, $28,1341-1349$. [CrossRef] [PubMed]

26. Tassi, E.; Pouget, J.; Petruzzelli, G.; Barbafieri, M. The effects of exogenous plant growth regulators in the phytoextraction of heavy metals. Chemosphere 2008, 71, 66-73. [CrossRef] [PubMed]

27. Rodríguez-Serrano, M.; Romero-Puertas, M.C.; Pazmiño, D.M.; Testillano, P.S.; Risueño, M.C.; del Río, L.A.; Sandalio, L.M. Cellular response of pea plants to cadmium toxicity: Cross talk between reactive oxygen species, nitric oxide, and calcium. Plant Physiol. 2009, 150, 229-243. [CrossRef]

28. Shafigh, M.; Ghasemi-Fasaei, R.; Ronaghi, A. Influence of plant growth regulators and humic acid on the phytoremediation of lead by maize in a Pb-polluted calcareous soil. Arch. Agron. Soil Sci. 2016, 62, 1733-1740. [CrossRef]

29. Wen, F.; Zhang, Z.; Bai, T.; Xu, Q.; Pan, Y. Proteomics reveals the effects of gibberellic acid (GA3) on salt-stressed rice (Oryza sativa L.) shoots. Plant Sci. 2010, 178, 170-175. [CrossRef]

30. Tuna, A.L.; Kaya, C.; Dikilitas, M.; Higgs, D. The combined effects of gibberellic acid and salinity on some antioxidant enzyme activities, plant growth parameters and nutritional status in maize plants. Environ. Exp. Bot. 2008, 62, 1-9. [CrossRef]

31. Alonso-Ramírez, A.; Rodríguez, D.; Reyes, D.; Jiménez, J.A.; Nicolás, G.; López-Climent, M.; Gómez-Cadenas, A.; Nicolás, C. Evidence for a role of gibberellins in salicylic acid-modulated early plant responses to abiotic stress in Arabidopsis seeds. Plant Physiol. 2009, 150, 1335-1344. [CrossRef]

32. Lüttge, U. Plant Physiology. In Encyclopedia of Ecology; Elsevier: Amsterdam, The Netherlands, 2019; pp. 549-557.

33. Rehman, M.; Liu, L.; Wang, Q.; Saleem, M.H.; Bashir, S.; Ullah, S.; Peng, D. Copper environmental toxicology, recent advances, and future outlook: A review. Environ. Sci. Pollut. Res. 2019, 26, 18003-18016. [CrossRef]

34. Parveen, A.; Saleem, M.H.; Kamran, M.; Haider, M.Z.; Chen, J.-T.; Malik, Z.; Rana, M.S.; Hassan, A.; Hur, G.; Javed, M.T.; et al. Effect of citric acid on growth, ecophysiology, chloroplast ultrastructure, and phytoremediation potential of jute (Corchorus capsularis L.) seedlings exposed to copper stress. Biomolecules 2020, 10, 592. [CrossRef]

35. Saleem, M.H.; Fahad, S.; Khan, S.U.; Din, M.; Ullah, A.; El Sabagh, A.; Hossain, A.; Llanes, A.; Liu, L. Copper-induced oxidative stress, initiation of antioxidants and phytoremediation potential of flax (Linum usitatissimum L.) seedlings grown under the mixing of two different soils of China. Environ. Sci. Pollut. Res. 2020, 27, 5211-5221. [CrossRef]

36. Habiba, U.; Ali, S.; Farid, M.; Shakoor, M.B.; Rizwan, M.; Ibrahim, M.; Abbasi, G.H.; Hayat, T.; Ali, B. EDTA enhanced plant growth, antioxidant defense system, and phytoextraction of copper by Brassica napus L. Environ. Sci. Pollut. Res. 2015, 22, 1534-1544. [CrossRef]

37. Liu, J.; Wang, J.; Lee, S.; Wen, R. Copper-caused oxidative stress triggers the activation of antioxidant enzymes via ZmMPK3 in maize leaves. PLoS ONE 2018, 13, e0203612. [CrossRef] 
38. Kamran, M.; Parveen, A.; Ahmar, S.; Malik, Z.; Hussain, S.; Chattha, M.S.; Saleem, M.H.; Adil, M.; Heidari, P.; Chen, J.-T. An overview of hazardous impacts of soil salinity in crops, tolerance mechanisms, and amelioration through selenium supplementation. Int. J. Mol. Sci. 2019, 21, 148. [CrossRef]

39. Thounaojam, T.C.; Panda, P.; Mazumdar, P.; Kumar, D.; Sharma, G.D.; Sahoo, L.; Sanjib, P. Excess copper induced oxidative stress and response of antioxidants in rice. Plant Physiol. Biochem. 2012, 53, 33-39. [CrossRef]

40. Zaheer, I.E.; Ali, S.; Rizwan, M.; Farid, M.; Shakoor, M.B.; Gill, R.A.; Najeeb, U.; Iqbal, N.; Ahmad, R. Citric acid assisted phytoremediation of copper by Brassica napus L. Ecotoxicol. Environ. Saf. 2015, 120, 310-317. [CrossRef]

41. Kanwal, U.; Ali, S.; Shakoor, M.B.; Farid, M.; Hussain, S.; Yasmeen, T.; Adrees, M.; Bharwana, S.A.; Abbas, F. EDTA ameliorates phytoextraction of lead and plant growth by reducing morphological and biochemical injuries in Brassica napus L. under lead stress. Environ. Sci. Pollut. Res. 2014, 21, 9899-9910. [CrossRef]

42. Fahad, S.; Bajwa, A.A.; Nazir, U.; Anjum, S.A.; Farooq, A.; Zohaib, A.; Sadia, S.; Nasim, W.; Adkins, S.; Saud, S.; et al. Crop production under drought and heat stress: Plant responses and management options. Front. Plant Sci. 2017, 8, 1147. [CrossRef] [PubMed]

43. Adrees, M.; Ali, S.; Rizwan, M.; Ibrahim, M.; Abbas, F.; Farid, M.; Zia-ur-Rehman, M.; Irshad, M.K.; Bharwana, S.A. The effect of excess copper on growth and physiology of important food crops: A review. Environ. Sci. Pollut. Res. 2015, 22, 8148-8162. [CrossRef] [PubMed]

44. Chen, J.; Shafi, M.; Li, S.; Wang, Y.; Wu, J.; Ye, Z.; Peng, D.; Yan, W.; Liu, D. Copper induced oxidative stresses, antioxidant responses and phytoremediation potential of Moso bamboo (Phyllostachys pubescens). Sci. Rep. 2015, 5, 13554. [CrossRef] [PubMed] 